\title{
FUNDUSZE UNIJNE WDRAŻANE POPRZEZ REGIONALNE PROGRAMY OPERACYJNE JAKO NEOENDOGENICZNY CZYNNIK ROZWOJU OBSZARÓW WIEJSKICH
}

\section{EU FUNDS IMPLEMENTED BY THE REGIONAL OPERATIONAL PROGRAMMES AS NEO-ENDOGENOUS DEVELOPMENT FACTOR FOR RURAL AREAS}

\section{Mirosław BICZKOWSKI}

Uniwersytet Mikołaja Kopernika

Wydział Nauk o Ziemi, Katedra Gospodarki Przestrzennej i Turyzmu

ul. Lwowska 1, 87-100 Toruń

mirbicz@umk.pl

Zarys treści: Artykuł podejmuje tematykę wzrastającego poziomu zróżnicowania rozwoju obszarów wiejskich, co decyduje o podziale na regiony dynamicznego wzrostu oraz obszary starające się, by dystans rozwojowy nie ulegał powiększeniu. Istotą w niwelowaniu różnic rozwojowych jest właściwe wykorzystanie potencjału endogenicznego tkwiącego w poszczególnych jednostkach terytorialnych. Opracowanie dotyczy problematyki właściwego kształtowania zrównoważonego rozwoju społeczno-gospodarczego obszarów wiejskich na bazie posiadanych uwarunkowań endogenicznych oraz odpowiedniego kierunkowania środków UE na wzmocnienie działań prowadzących do optymalnego wykorzystania posiadanych zasobów. W celu kompleksowej oceny oddziaływania funduszy na rozwój społeczno-gospodarczy posłużono się przyjętym pakietem wskaźników ekonomicznych oraz wskaźnikami syntetycznymi obliczonymi dla potencjału społeczno-gospodarczego (endogenicznego) obszarów wiejskich (w ujęciu regionalnym) oraz poziomu absorpcji środków wdrażanych poprzez 16 Regionalnych Programów Operacyjnych. Pozwoliło to na określenie relacji i współzależności zachodzących pomiędzy obiema płaszczyznami. Tak ukierunkowaną analizę odniesiono do koncepcji neoendogenicznego rozwoju gospodarczego.

Słowa kluczowe: fundusze UE, rozwój neoendogeniczny, obszary wiejskie, Regionalne Programy Operacyjne, rozwój społeczno-gospodarczy.

\section{Wstęp}

Od wstąpienia Polski do Unii Europejskiej minęła już cała dekada. W tym czasie nasz kraj był beneficjentem funduszy unijnych częściowo z perspektywy 2000-2006 (Polska i pozostałe kraje, które wówczas wstąpiły do Wspólnoty korzystały z funduszy jedynie od maja 2004 do końca 2006 r.) oraz perspektywy 2007-2013, która była pierwszą w pełni wdrażaną w Polsce i rozliczanie której powinno zakończyć się z końcem 2015 r. Stanowi 
to zatem dobry moment na dokonanie bilansu i podsumowań kończącej się perspektywy finansowej. Przedmiotem analizy w niniejszym artykule jest ocena funduszy unijnych wdrażanych poprzez Regionalne Programy Operacyjne w każdym z województw (razem 16 RPO), zwłaszcza w odniesieniu do obszarów wiejskich. Tereny te w ostatniej dekadzie istotnie skorzystały z możliwości rozwoju przy wsparciu środkami zewnętrznymi, jakimi są fundusze UE, wzmacniając jednocześnie własny, endogeniczny potencjał. Pamiętać należy, iż polska wieś przez całe dziesięciolecia pozostawała na uboczu głównych procesów rozwojowych, co przyczyniło się do jej istotnego zapóźnienia cywilizacyjnego na wielu płaszczyznach: niedorozwoju infrastruktury społecznej i technicznej, niskiego poziomu wykształcenia ludności, braku inwestycji w poprawę wyglądu i fizjonomii wsi oraz nieuporządkowanej przestrzeni publicznej (izby muzealne, skwery, remizy strażackie, folwarki itp.), braku organizacji placówek kulturalnych, infrastruktury sportowej i turystycznej czy rozdrobnienia gospodarstw rolnych (Koreleski 2007; Biczkowski 2013). Wpłynęło to na znacznie niższy standard życia mieszkańców wsi oraz niską atrakcyjność obszarów wiejskich dla potencjalnych inwestorów. Dostrzegano zatem konieczność istotnych zmian i wsparcia rozwoju wsi, i to nie tylko w aspekcie rolnictwa, ale także szeroko rozumianego rozwoju społeczno-gospodarczego. Oprócz czynnika ekonomicznego ważne są bowiem również kwestie społeczne. Jak zauważa M. Wójcik (2010), akcesja Polski do UE poszerzyła zakres uwarunkowań decydujących o przekształceniach wsi, lecz nie była jedynym, determinującym czynnikiem. Istotna jest zmiana mentalności ludzi, bowiem gdyby nie ona, to zmiany prawdopodobnie nie przybrałaby obecnej formy.

Zmiany w rozwoju społeczno-gospodarczym są wypadkową oddziaływania dwóch sił: czynników endogenicznych (m.in.: kapitał ludzki, potencjał i struktura gospodarki, stopień rozwoju infrastruktury, stan i jakość środowiska przyrodniczego) oraz oddziaływujących na lokalne struktury czynników egzogenicznych. Jak podaje K. Heffner (2007), utrzymywanie się zróżnicowania poziomu rozwoju społeczno-gospodarczego obszarów wiejskich w skali lokalnej, jak i regionalnej to efekt równoczesnego oddziaływania czynników o charakterze egzo i endogenicznym. W mechanizmy mające istotny wpływ na kształtowanie lokalnych struktur społeczno-gospodarczych silnie wpisują się fundusze Unii Europejskiej, które stymulują szanse przyspieszenia rozwoju poszczególnych gmin oraz stanowią impuls do zaktywizowania i pełniejszego wykorzystania posiadanych zasobów. Współzależność pomiędzy dwiema grupami uwarunkowań akcentuje koncepcja neoendogenicznego rozwoju obszarów wiejskich (Ray 1997, 2006; Klekotko 2005; Biczkowski 2013), która zakłada wykorzystywanie wszystkich możliwych zasobów lokalnych w celu jak największej absorpcji potencjalnych czynników zewnętrznych, aby z efekcie pomnażać posiadany potencjał własny.

Koncepcja rozwoju neoendogenicznego wpisuje się w oddolne procesy kształtowania rozwoju jednostki samorządowej, bowiem niejako z samej istoty zakłada ona budowanie jej potencjału w oparciu o własne zasoby, które są istotnie zróżnicowane. Nie ma zatem jednej ścieżki rozwoju, którą można by powielać. Wśród najważniejszych czynników wewnętrznych determinujących rozwój obszarów wiejskich można wymienić: potencjał środowiska naturalnego, wysoki poziom produkcji rolniczej, rozwinięte przetwórstwo bądź przemysł, jakość kapitału społecznego, posiadane surowce, dobre zagospodarowanie infrastrukturalne, walory turystyczne, walory kulturowe czy renta położenia geograficznego dla jednostek położonych w pobliżu biegunów rozwojowych i metropolii. Rozwój neoendogeniczny opiera się na równowadze pomiędzy wykorzystaniem zasobów danego 
obszaru (uwarunkowania endogeniczne) a środkami pozyskiwanymi ze źródeł zewnętrznych (uwarunkowania egzogeniczne) i stanowi pewnego rodzaju kompromis pomiędzy teoriami rozwoju egzo i endogennego (Adamski i in. 2007).

Fundusze unijne, ich rola i wpływ na kształtowanie rozwoju poszczególnych jednostek samorządowych nie doczekały się jeszcze solidnego osadzenia na gruncie teoretycznym. Jest to w Polsce stosunkowo nowy, chociaż silnie oddziaływujący, czynnik rozwoju lokalnego i regionalnego, także w odniesieniu do obszarów wiejskich. W pierwszej dekadzie członkostwa Polski w Unii Europejskiej środki te stały się bowiem jednym z najistotniejszych czynników rozwojowych i stanowią o większości strategicznych inwestycji, realizowanych zarówno na szczeblu lokalnym (gmina), regionalnym (województwo), jak i ogólnokrajowym (Biczkowski 2013). Wpisują się tym samym w założenia koncepcji rozwoju neoendogenicznego, co umożliwia ich ocenę w świetle powyżej teorii.

\section{Założenia badawcze i metodyka}

Rozpatrując obecny rozwój społeczno-gospodarczy obszarów wiejskich z punktu widzenia impulsów rozwojowych, szczególną uwagę należy zwrócić na dwa aspekty: (1) możliwość kształtowania rozwoju zrównoważonego w oparciu o wykorzystywanie własnego, endogenicznego potencjału, (2) stymulowanie rozwoju poprzez wykorzystanie źródeł zewnętrznych, w tym funduszy strukturalnych UE.

Pierwsze próby oceny oddziaływania funduszy UE na rozwój polskich regionów w świetle koncepcji neoendogenicznego rozwoju zastosowano w odniesieniu do wpływu środków Wspólnej Polityki Rolnej na zmiany makroekonomicznych wskaźników rozwojowych (Biczkowski 2013). Niniejszy artykuł jest kolejną próbą oceny oddziaływania środków UE na rozwój społeczno-gospodarczy obszarów wiejskich w świetle wspomnianej teorii. Tym razem ocenie podlegały środki z 16 Regionalnych Programów Operacyjnych, przeznaczone na rozwój gmin wiejskich. Inna jest także płaszczyzna oceny, bowiem została ona skierowana na analizę porównawczą dwóch syntetycznych wskaźników: poziomu rozwoju społeczno-gospodarczego oraz poziomu absorpcji środków UE przez obszary wiejskie.

Szerokie spectrum działań uwzględnionych w programach RPO poszczególnych województw, umożliwiające realizację szerokiego wachlarza przedsięwzięć, wpłynęło na zróżnicowanie projektów i złożonych wniosków. Było to efektem świadomych inicjatyw władz samorządowych oraz pozostałych beneficjentów, które zmierzały do wykorzystania istniejącego potencjału oraz eliminowania słabości poszczególnych jednostek samorządowych, wpływając tym samym na podniesienie ich konkurencyjności. W odróżnieniu od polityki realizowanej w poprzednich dekadach, mającej na celu przede wszystkim wspieranie konkretnych sektorów gospodarki, dzięki założeniom RPO nastąpiło pewne przeorientowanie założeń na rzecz szerszego wsparcia inicjatyw lokalnych realizowanych w lokalnych jednostkach samorządowych, uwzględniając przy tym aspekty rozwoju społeczno-gospodarczego.

W takim podejściu za najistotniejsze kryterium oceny środków unijnych jako czynnika neoendogenicznego należy uznać analizę wzajemnych zależności zachodzących pomiędzy wewnętrznym potencjałem absorpcyjnym określonym w odniesieniu do obszarów wiejskich każdego z regionów (funkcja adaptacyjna) a poziomem absorpcji funduszy UE oraz ich wpływem na podniesienie wskaźników gospodarczych (funkcja akceleracyjna). Obie, tak zdefiniowane płaszczyzny analizy, wzajemnie wywierają na siebie wpływ, rzutując tym 
samym na zmiany w rozwoju społeczno-gospodarczym zachodzące na obszarach wiejskich każdego z regionów.

Artykuł składa się z dwóch zasadniczych części. Pierwsza dotyczy określenia poziomu rozwoju społeczno-gospodarczego obszarów wiejskich w ujęciu regionalnym, który stanowi tło do dalszej analizy. Druga część koncentruje się na ocenie wpływu funduszy unijnych (na podstawie płatności zrealizowanych w ramach działań 16 Regionalnych Programów Operacyjnych), którą przeprowadzono dwutorowo. Pierwszy z aspektów dotyczy analizy porównawczej wzajemnego oddziaływania dwóch przyjętych płaszczyzn: wskaźnika uwarunkowań społeczno-gospodarczych oraz wskaźnika poziomu absorpcji środków z 16 RPO przez beneficjentów z gmin wiejskich (dane zagregowano do regionów). Drugą płaszczyzną oceny jest określenie relacji udziału funduszy unijnych w stosunku do wskaźników społeczno-gospodarczych przyjętych do analizy: produktu krajowego brutto (PKB), poziomu dochodów budżetów wojewódzkich oraz wartości dodanej brutto ogółem, stanowiących wyznacznik siły ekonomicznej poszczególnych województw, traktowanych w tym ujęciu jako miara wewnętrznego (endogenicznego) potencjału każdego z regionów. Biorąc pod uwagę, że celem niniejszego artykułu nie jest szczegółowa analiza poziomu rozwoju społeczno-gospodarczego, a stanowi ona jedynie tło do oceny oddziaływania funduszy UE, dane zagregowano i przedstawiono w ujęciu regionalnym. Należy także zaznaczyć, iż zgodnie z zasadami obowiązującymi w PROW do terenów wiejskich, oprócz gmin stricte wiejskich oraz części wiejskich gmin miejsko-wiejskich, zalicza się także małe miasta, do 5 tys. mieszkańców, które również zostały ujęte w niniejszym artykule. Zakres czasowy objął perspektywę finansową z lat 2007-2013, kiedy to były wdrażane Regionalne Programy Operacyjne.

Przyjęte do wyznaczenia poziomu rozwoju społeczno-gospodarczego obszarów wiejskich cechy określające ich potencjał wewnętrzny (ujęcie regionalne) poddano procedurze standaryzacji i ujęto w formie wskaźnika syntetycznego - średniej wartości znormalizowanej (Racine i Raymond 1977). Następnie dokonano podziału regionów na cztery grupy o: wysokim (pow. 0,50б), średnim $(0,50-0,00 \sigma)$, niskim $(0,00--0,50 \sigma)$ i bardzo niskim (pon. -0,50б) poziomie rozwoju społeczno-gospodarczego. Tak ukierunkowana analiza umożliwiła wydzielenie obszarów szczególnie predysponowanych (jednostki zaliczone do grup o niskim i bardzo niskim poziomie rozwoju) do wsparcia rozwoju z funduszy UE, jako że jednym z podstawowych celów tych środków jest wyrównywanie szans rozwojowych poszczególnych regionów.

\section{Rozwój społeczno-gospodarczy obszarów wiejskich - ujęcie regionalne}

Przesunięcie środka ciężkości z wspierania konkretnych sektorów gospodarki na rzecz inicjatyw lokalnych ma zapobiec wspieraniu poszczególnych sektorów gospodarki w izolacji od siebie oraz stosowaniu standardowych mierników w ocenie wymaganej pomocy pomijających aspekty położenia oraz zróżnicowania społeczno-gospodarczego. Koncepcja rozwoju neoendogenicznego zakłada, że poszczególne obszary mogą same kształtować swoją politykę rozwojową poprzez odpowiednie sterowanie interwencjami zewnętrznymi. Równocześnie zakłada się, że obszary te posiadają odpowiedni potencjał własny, aby móc wziąć odpowiedzialność za rozwój społeczno-gospodarczy oraz odpowiednio wykorzystać egzogeniczne instrumenty wsparcia (Biczkowski 2013). 
Trendy społeczno-gospodarcze obserwowane na terenach wiejskich w ostatnich latach cechują się znaczną dynamiką i prowadzą do zwiększenia skali zróżnicowania rozwojowego poszczególnych obszarów. Liczba ludności na terenach wiejskich w ostatniej dekadzie wzrosła o ok. 210 tys. mieszkańców. Jest to następstwem utrzymywania się trendów migracyjnych na terenach położonych w pobliżu aglomeracji miejskich, gdzie następuje przyrost ludności, podczas gdy wiele wsi położonych peryferyjnie ulega depopulacji. Poza tym polska wieś charakteryzuje się rozproszoną siecią osadniczą i generalnie małą liczbą mieszkańców w poszczególnych miejscowościach. Utrudnia to rozwój tych obszarów, nie sprzyja utrzymaniu żywotności społecznej, podraża koszty budowy infrastruktury i często wyklucza podejmowanie działalności pozarolniczej, głównie z uwagi na brak odpowiedniej liczby jej odbiorców. Rozproszenie sieci osadniczej przekłada się m.in. na stan rozwoju sieci infrastrukturalnych. Na obszarach wiejskich udział ludności korzystającej z instalacji wodociągowej wynosi 75\% (wzrost o 4,5\% od 2003 r.), sieci kanalizacyjnej 24\% (wzrost o 7,6\%), zaś sieci gazowej pozostaje na podobnym poziomie - ok. 19\%. Jednocześnie, m.in. w wyniku coraz większej dostępności nowoczesnych technologii i powstawania oczyszczalni ścieków o zwiększonej wydajności, nastąpiła istotna poprawa w kwestii przepustowości oczyszczalni i wzrost liczby ludności wiejskiej obsługiwanej przez oczyszczalnie (o 66\%). Również warunki dotyczące rozwoju przedsiębiorczości na obszarach wiejskich są utrudnione, m.in. z powodu znacznego rozproszenia rynku i klientów, wysokich kosztów zaopatrzenia, słabej promocji, niedorozwoju infrastruktury, słabego wykształcenia ludności wiejskiej oraz trudnego dostępu do usług doradczych i informacji (Wpływ funduszy... 2010). Pomimo trudności w prowadzeniu działalności gospodarczej na obszarach wiejskich w ostatniej dekadzie zaobserwować można wzrost ogólnej liczby podmiotów o ok. 80 tys., do ponad 930 tys., co stanowi 1/4 ogółu podmiotów zarejestrowanych w rejestrze REGON w kraju.

Na potrzeby analizy społeczno-gospodarczej, stanowiącej punkt odniesienia do dalszej oceny oddziaływania środków UE, określono poziom rozwoju społeczno-gospodarczego obszarów wiejskich dla każdego z regionów. W tym celu przyjęto następujący zestaw wskaźników (dane dla 2013 r.): przeciętne miesięczne wynagrodzenie brutto w gospodarce narodowej ogółem, wskaźnik zatrudnienia na wsi osób w wieku 15 lat i więcej, produkt krajowy brutto na 1 mieszkańca, osoby fizyczne prowadzące działalność gospodarczą na 100 osób w wieku produkcyjnym, procentowy udział regionów w produkcji globalnej ogółem, globalna produkcja rolnicza w przeliczeniu na 1 ha użytków rolnych, nakłady inwestycyjne na 1 mieszkańca (średnia arytmetyczna z lat 2007-2013). Na bazie przeprowadzonej procedury standaryzacji powyższe cechy ujęto w postaci ujednoliconego wskaźnika syntetycznego i dokonano podziału regionów na cztery grupy. Do pierwszej zaliczono regiony o najniższym wskaźniku względem średniej dla kraju i są to województwa: warmińsko-mazurskie $(-1,07 \sigma)$, podkarpackie $(-0,77 \sigma)$, podlaskie $(-0,55 \sigma)$ i świętokrzyskie $(-0,55 \sigma)$. Druga grupę reprezentują województwa o niskim poziomie rozwoju: lubuskie $(-0,46 \sigma)$, lubelskie $(-0,40 \sigma)$, opolskie $(-0,33 \sigma)$, kujawsko-pomorskie $(-0,29 \sigma)$ i zachodniopomorskie $(-0,19 \sigma)$. Trzecią grupę, o wartościach wskaźnika oscylujących wokół średniej bądź nieco powyżej tworzą: małopolskie $(0,00 \sigma)$, pomorskie $(0,17 \sigma)$, dolnośląskie $(0,39 \sigma)$, łódzkie $(0,43 \sigma)$ oraz śląskie $(0,47 \sigma)$. Grupę o wysokim poziomie rozwoju społeczno-gospodarczego reprezentują dwa regiony: wielkopolski $(0,87 \sigma)$ oraz mazowiecki $(2,28 \sigma)$ (por. tab. 1). 
Tabela 1. Podstawowe wskaźniki rozwoju społeczno-gospodarczego

\begin{tabular}{|c|c|c|c|c|c|c|c|c|}
\hline $\begin{array}{l}\text { Jednostka } \\
\text { terytorialna }\end{array}$ & 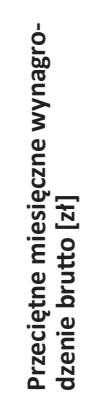 & 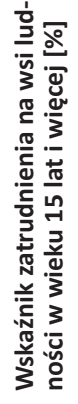 & 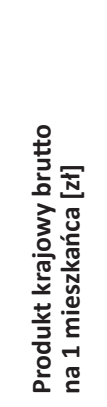 & 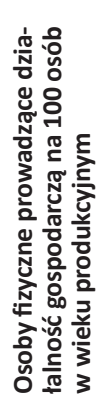 & 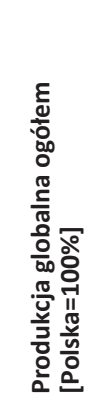 & 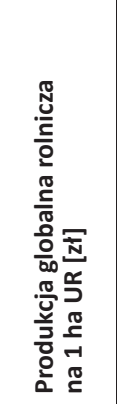 & 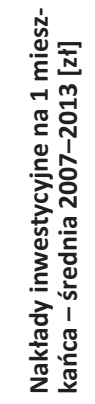 & 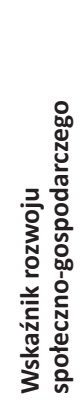 \\
\hline Dolnośląskie & 3654,6 & 48,7 & 47440 & 12,6 & 9,1 & 5419 & 7092 & 0,39 \\
\hline Kujawsko-pomorskie & 3163,6 & 49,4 & 34095 & 10,7 & 4,4 & 8093 & 4434 & $-0,29$ \\
\hline Lubelskie & 3306,1 & 52,1 & 29479 & 9,5 & 3,5 & 6573 & 4509 & $-0,40$ \\
\hline Lubuskie & 3114,7 & 47,8 & 34862 & 11,9 & 2,2 & 6090 & 5168 & $-0,46$ \\
\hline Łódzkie & 3315,6 & 53,9 & 39080 & 11,5 & 5,8 & 7889 & 6680 & 0,43 \\
\hline Małopolskie & 3372,6 & 50,3 & 36961 & 12,3 & 7,3 & 6214 & 5231 & 0,00 \\
\hline Mazowieckie & 4514,4 & 52,1 & 66755 & 14,9 & 22,4 & 8980 & 8908 & 2,28 \\
\hline Opolskie & 3281,5 & 49,7 & 33888 & 11,1 & 2,2 & 6926 & 4746 & $-0,33$ \\
\hline Podkarpackie & 3147,2 & 48,7 & 29333 & 8,9 & 3,6 & 4490 & 5643 & $-0,77$ \\
\hline Podlaskie & 3258,7 & 49,6 & 30055 & 9,9 & 2,1 & 6462 & 4610 & $-0,55$ \\
\hline Pomorskie & 3596,0 & 47,7 & 41045 & 13,5 & 6,3 & 6303 & 6031 & 0,17 \\
\hline Śląskie & 3786,1 & 48,1 & 44372 & 11,5 & 13,1 & 7658 & 6002 & 0,47 \\
\hline Świętokrzyskie & 3165,9 & 49,6 & 31459 & 10,7 & 2,3 & 6802 & 3895 & $-0,55$ \\
\hline Warmińsko-mazurskie & 3106,9 & 44,4 & 30065 & 9,4 & 2,6 & 5319 & 4275 & $-1,07$ \\
\hline Wielkopolskie & 3335,9 & 54,0 & 44567 & 13,6 & 9,7 & 10154 & 5450 & 0,87 \\
\hline Zachodniopomorskie & 3299,0 & 46,2 & 35334 & 14,8 & 3,4 & 5017 & 6249 & $-0,19$ \\
\hline Polska & 3401,2 & 49,5 & 38049,4 & 11,7 & 100,0 & 6774,3 & 5557,7 & - \\
\hline
\end{tabular}

Źródło: opracowanie własne na podstawie danych BDL GUS, Warszawa.

Taki rozkład przestrzenny nie jest niczym nowym, raczej potwierdza ogólne prawidłowości obserwowane od wielu lat. Na przestrzeni ostatniej dekady zaobserwować możemy jednak nieznaczne zmiany w hierarchii pomiędzy poszczególnymi regionami. W górę przesuwają się np. lubelskie, kujawsko-pomorskie czy dolnośląskie, zaś odwrotny kierunek obserwujemy w przypadku województwa warmińsko-mazurskiego czy zachodniopomorskiego.

Celem zachowania właściwej perspektywy należy dodać, iż fakt, że niektóre regiony są znacznie poniżej średniej, nie oznacza, że się nie rozwijają. Przeciwnie, również tam obserwujemy rozwój, w niektórych obszarach nawet znaczący, czego potwierdzeniem jest wzrost wartości wszystkich wskaźników przyjętych do analizy w okresie 2007-2013 w każdym z regionów. Jednocześnie rozwój ten nie jest na tyle dynamiczny, aby umożliwił „zasypywanie” luki rozwojowej i regiony te w odniesieniu do średniej dla kraju ciągle odznaczają się mniej korzystnymi uwarunkowaniami. Dotyczy to zwłaszcza regionów tzw. 


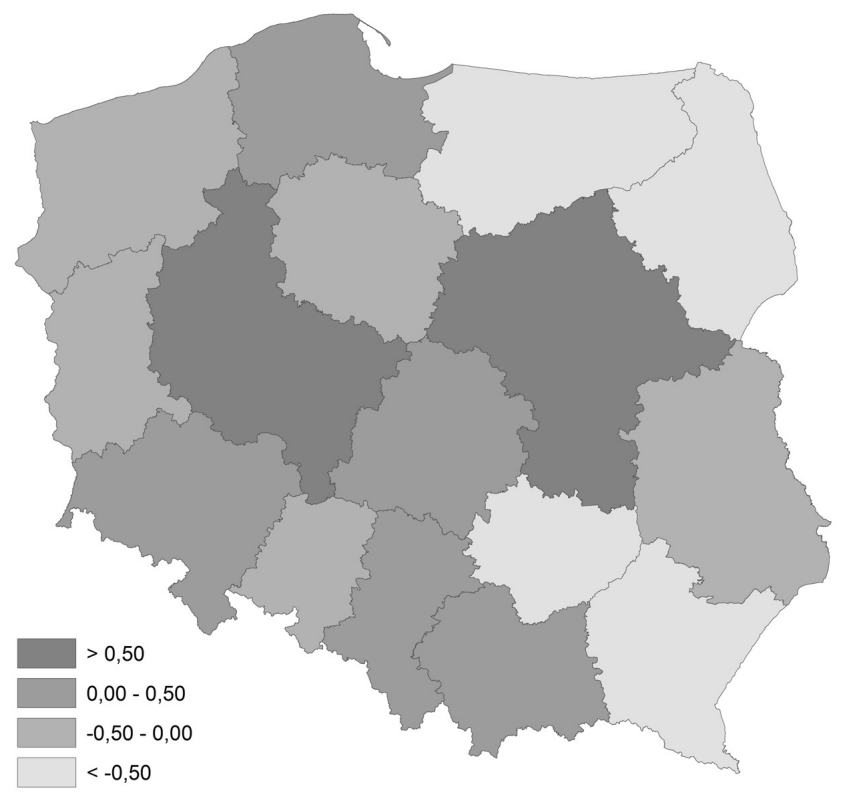

Ryc. 1. Syntetyczny wskaźnik poziomu rozwoju społeczno-gospodarczego (wg odchylenia od średniej - $\sigma$ ) Synthetic indicator of socio-economic development (by deviation from mean - $\sigma$ ) Źródło/Source: tabela1.

„ściany wschodniej”, chociaż zaobserwować można stopniowy awans woj. lubelskiego, które obecnie jest bliższe takim regionom jak opolskie czy kujawsko-pomorskie aniżeli sąsiednim podkarpackiemu i podlaskiemu.

Szczegółowa analiza rozwoju społeczno-gospodarczego obszarów wiejskich w obrębie poszczególnych regionów pozwalająca na bardziej precyzyjną obserwację wskazuje, iż pomimo ogólnego wzrostu tereny te cechują się znacznym zróżnicowaniem. W obecnych realiach jednym z najistotniejszych czynników wywierających wpływ na konkurencyjność tych obszarów jest ich lokalizacja względem dużych aglomeracji miejskich. Na terenach tych coraz słabszą rolę odgrywa rolnictwo, a znaczenia nabierają funkcje nierolnicze handel i usługi, rozwija się mieszkalnictwo, a to przekłada się na relatywnie wyższe dochody własne tych gmin w porównaniu z dochodami gmin położonych peryferyjnie. Innym rodzajem obszarów, na których następuje przyspieszony rozwój pozarolniczego rynku pracy, są te położone wzdłuż głównych ciągów komunikacyjnych. Na drugim biegunie znajdują się obszary peryferyjne, które charakteryzują się stagnacją oraz ubytkiem ludności (Wpływ funduszy... 2010). Jedną z podstawowych koncepcji rozwojowych przyjętych dla wzmacniania rozwoju gospodarczego dla terenów wiejskich, ujętych w zapisach Narodowych Strategicznych Ram Odniesienia 2007-2013, jest budowanie ścisłych powiązań komunikacyjnych, teleinformatycznych, gospodarczych, usługowych i kulturalnych pomiędzy terenami zurbanizowanymi a otaczającymi je obszarami wiejskimi, co w efekcie ma prowadzić do rozprzestrzeniania się wzrostu gospodarczego (NSRO 2006). 


\section{Przestrzenna alokacja środków UE wdrażanych poprzez Regionalne Programy Operacyjne}

W ramach szesnastu Regionalnych Programów Operacyjnych zrealizowano dotychczas blisko 47 tys. umów na łączną kwotę ok. 140 mld zł, z czego dofinansowanie środkami UE wyniosło 76 mld zł (wg stanu na 31.12.2014). Z tej puli do analizy przyjęto ostatecznie 16154 umowy spełniające kryteria projektów realizowanych na obszarach wiejskich, do których zaliczono gminy wiejskie oraz miasta do 5 tys. mieszkańców (zgodnie z kryterium przyjętym w PROW). Łączna kwota dofinansowania przedsięwzięć na obszarach wiejskich ze środków unijnych wyniosła blisko 24,4 mld zł. Analiza struktury rozdysponowanych środków w układzie regionalnym wykazała, że największe środki ujmowane w wartościach bezwzględnych, trafiły do beneficjentów z województw: mazowieckiego (2,5 mld zł), wielkopolskiego (2,4 mld zł) oraz podkarpackiego (2,3 mld zł). Natomiast najniższym poziomem absorpcji odznaczają się beneficjenci z województw: lubuskiego (700 mln zł), opolskiego (736 mln zł) i podlaskiego (940 mln zł) (por. ryc. 2).

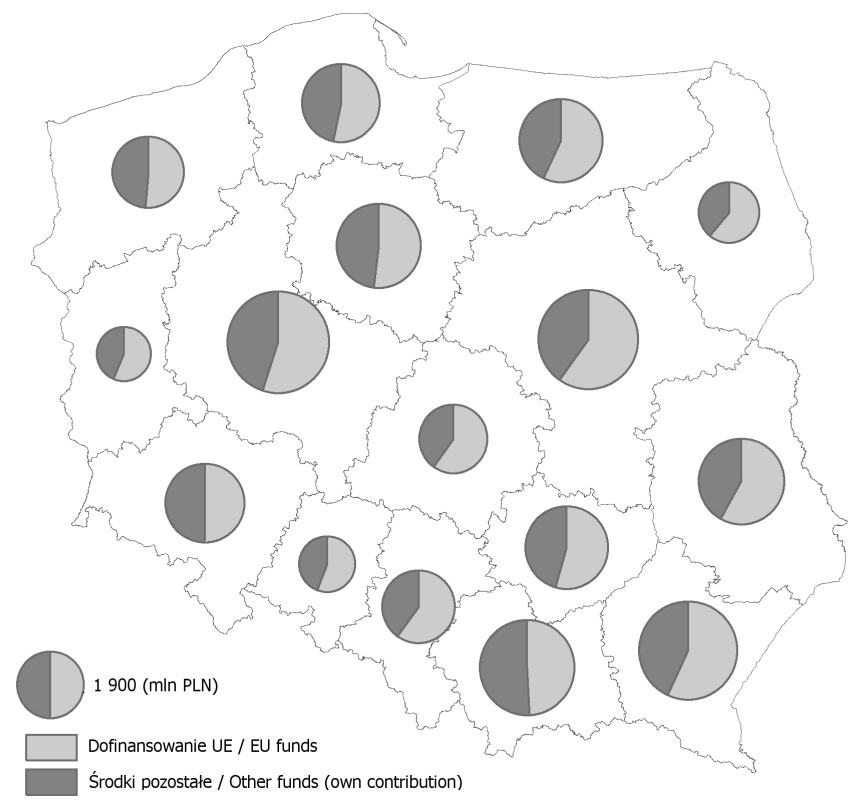

Ryc. 2. Wielkość oraz struktura dofinansowania projektów zrealizowanych w ramach RPO Value and structure of financing projects implemented under the ROP Źródło/Source: opracowanie własne/own elaboration.

Warto zauważyć, iż specyfika programów RPO umożliwiała korzystanie z nich szerokiej gamie potencjalnych beneficjentów, którymi były nie tylko samorządy, ale również przedsiębiorcy, podmioty z obszaru kultury, turystyki, sportu, instytucje kościelne, wspólnoty mieszkaniowe, uczelnie i szkoły wyższe, szpitale i podmioty z sektora służby zdrowia, sektor pozarządowy i wiele innych. Jeśli jako miarę dążeń do poprawy sytuacji społeczno-gospodarczej na wsi przyjąć aktywność inwestycyjną samorządów oraz pozostałych beneficjentów z terenów wiejskich, to do grona liderów należy zaliczyć województwa: kujawsko-pomorskie (2062 zrealizowane wnioski), lubelskie (1577) oraz podkarpackie 
(1435). Najniższą aktywność obserwuje się w województwach: lubuskim (373), podlaskim (427) i opolskim (521).

Z uwagi na istotne różnice występujące pomiędzy regionami, związane chociażby z liczbą ostatecznych beneficjentów, liczbą mieszkańców, zróżnicowanym poziomem rozwoju gospodarczego, infrastrukturalnego itp., do szczegółowej analizy przyjęto zestaw wskaźników społeczno-gospodarczych, które ilustrują faktyczną rolę i oddziaływanie funduszy UE w rozwoju obszarów wiejskich. Najwyższy poziom aktywności beneficjentów mierzonej liczbą wniosków zrealizowanych na 10 tys. mieszkańców występuje w województwie kujawsko-pomorskim $(9,8)$ i lubelskim $(7,3)$, najniższy w mazowieckim $(2,0)$ oraz łódzkim i śląskim $(2,7)$. Pod względem absorpcji funduszy UE z programów RPO przeliczonej na liczbę mieszkańców najwyższe wskaźniki odnotowano w województwach: świętokrzyskim (1229 zł/1 mieszkańca), warmińsko-mazurskim (1145) i podkarpackim (1090). Na przeciwległym biegunie znajdują się województwa: śląskie (292), dolnośląskie (453), łódzkie (466) i mazowieckie (473) (por. tab. 2, ryc. 3).

Tabela 2. Podstawowe wskaźniki poziomu absorpcji środków UE z programów RPO

\begin{tabular}{|c|c|c|c|c|c|c|c|}
\hline \multirow[b]{2}{*}{$\begin{array}{l}\text { Jednostka } \\
\text { terytorialna }\end{array}$} & \multicolumn{3}{|c|}{ Udział funduszy z RPO } & \multirow[b]{2}{*}{ 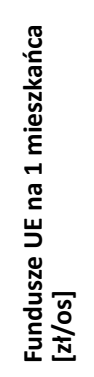 } & \multirow[b]{2}{*}{ 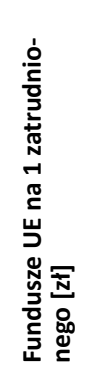 } & \multirow[b]{2}{*}{ 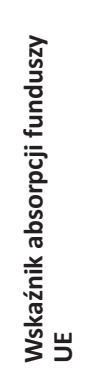 } & \multirow[b]{2}{*}{ 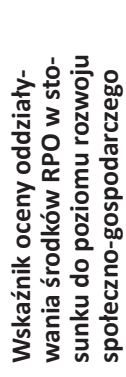 } \\
\hline & 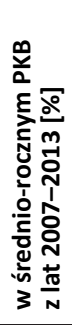 & 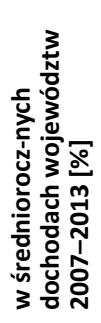 & 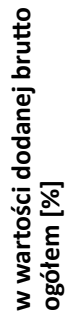 & & & & \\
\hline Dolnośląskie & 1,1 & 1,0 & 1,3 & 453,2 & 1675,9 & $-1,045$ & $-1,43$ \\
\hline Kujawsko-pomorskie & 2,4 & 2,1 & 2,8 & 739,8 & 3404,0 & 0,114 & 0,40 \\
\hline Lubelskie & 3,2 & 2,3 & 3,7 & 828,6 & 4472,0 & 0,716 & 1,12 \\
\hline Lubuskie & 2,2 & 1,4 & 2,5 & 683,7 & 3164,4 & $-0,108$ & 0,35 \\
\hline Łódzkie & 1,4 & 1,4 & 1,6 & 466,3 & 1976,6 & $-0,831$ & $-1,26$ \\
\hline Małopolskie & 1,7 & 1,7 & 2,0 & 560,4 & 2266,7 & $-0,546$ & $-0,55$ \\
\hline Mazowieckie & 0,8 & 1,0 & 0,9 & 473,1 & 1111,8 & $-1,231$ & $-3,51$ \\
\hline Opolskie & 2,4 & 1,6 & 2,7 & 725,4 & 3729,2 & 0,053 & 0,38 \\
\hline Podkarpackie & 4,3 & 2,7 & 4,8 & 1090,3 & 5437,6 & 1,506 & 2,28 \\
\hline Podlaskie & 2,9 & 1,9 & 3,3 & 783,2 & 4381,1 & 0,529 & 1,08 \\
\hline Pomorskie & 1,7 & 1,6 & 1,9 & 597,2 & 2501,0 & $-0,538$ & $-0,71$ \\
\hline Śląskie & 0,7 & 1,0 & 0,8 & 291,6 & 1086,8 & $-1,365$ & $-1,84$ \\
\hline Świętokrzyskie & 4,3 & 2,8 & 4,9 & 1229,0 & 6588,1 & 1,696 & 2,25 \\
\hline Warmińsko-mazurskie & 4,3 & 2,7 & 4,9 & 1144,5 & 6038,5 & 1,678 & 2,75 \\
\hline Wielkopolskie & 1,8 & 2,0 & 2,1 & 698,8 & 2320,4 & $-0,406$ & $-1,27$ \\
\hline Zachodniopomorskie & 2,0 & 1,5 & 2,3 & 637,7 & 3065,6 & $-0,221$ & $-0,03$ \\
\hline Polska & 2,3 & 1,8 & 2,7 & 712,7 & 3326,2 & - & - \\
\hline
\end{tabular}

Źródło: opracowanie własne na podstawie danych MRR oraz Portalu Funduszy Europejskich. 


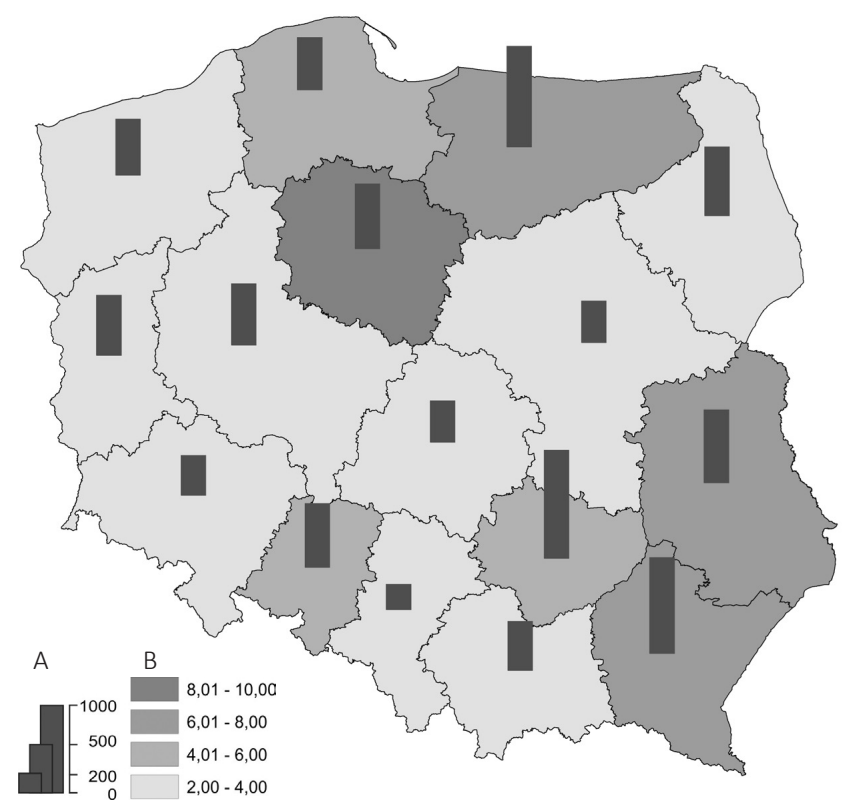

Ryc. 3. Wskaźnik absorpcji funduszy UE w przeliczeniu na 1 mieszkańca [zł/os] (A) oraz liczba zrealizowanych projektów w przeliczeniu na 10 tys. mieszkańców (B)

Absorption rate of EU funds per capita [PLN / person] (A) and number of completed projects per 10 thous. inhabitants (B)

Źródło/Source: opracowanie własne/own elaboration.

W celu uogólnienia zagadnienia absorpcji funduszy obliczono ujednolicony wskaźnik syntetyczny poziomu absorpcji środków UE na podstawie pięciu cech: udziału funduszy UE w średniorocznym PKB z lat 2007-2013, udziału funduszy UE w średniorocznych dochodach województw 2007-2013, udziału funduszy UE w wartości dodanej brutto ogółem, wielkości funduszy UE na 1 mieszkańca, wielkości funduszy UE na 1 zatrudnionego. Tak ujęta analiza wykazała, iż relatywnie najwyższym poziomem absorpcji odznaczają się obszary wiejskie z województw tzw. „ściany wschodniej”, które od lat cechuje najniższy poziom rozwoju społeczno-gospodarczego. Zdecydowanie powyżej średniej pod względem poziomu absorpcji znajdują się trzy województwa: świętokrzyskie $(1,70 \sigma)$, warmińsko-mazurskie $(1,68 \sigma)$ i podkarpackie $(1,51 \sigma)$, ponadto do grupy tej zaliczają się jeszcze lubelskie $(0,72 \sigma)$ i podlaskie $(0,53 \sigma)$. Do grupy o niskim poziomie absorpcji należą przede wszystkim województwa powszechnie uchodzące za zamożne i lepiej rozwinięte infrastrukturalnie i gospodarczo: śląskie $(-1,34 \sigma)$, mazowieckie $(-1,23 \sigma)$, dolnośląskie $(-1,00 \sigma)$, a także łódzkie $(-0,83 \sigma)$, małopolskie $(-0,55 \sigma)$ i pomorskie $(-0,54 \sigma)$ (por. ryc. 4).

Taki rozkład wskaźnika absorpcji oznacza, iż jeden z celów przyświecający wdrażaniu funduszy unijnych, dotyczący wyrównywania rozwoju pomiędzy regionami, znajduje swoje potwierdzenie w rzeczywistych kierunkach alokacji środków UE. Powinno to sprzyjać zdynamizowaniu rozwoju wsi na terenach uchodzących do tej pory za niedoinwestowane, z niską jakością poziomu życia oraz poprawie ich sytuacji ekonomicznej. Jednocześnie należy mieć na uwadze, iż pod względem wartości bezwzględnych występuje wyraźna dysproporcja w absorpcji na korzyść regionów zamożniejszych, gdzie położone są duże aglomeracje stanowiące bieguny dynamicznego rozwoju silenie oddziaływujące na otoczenie. 


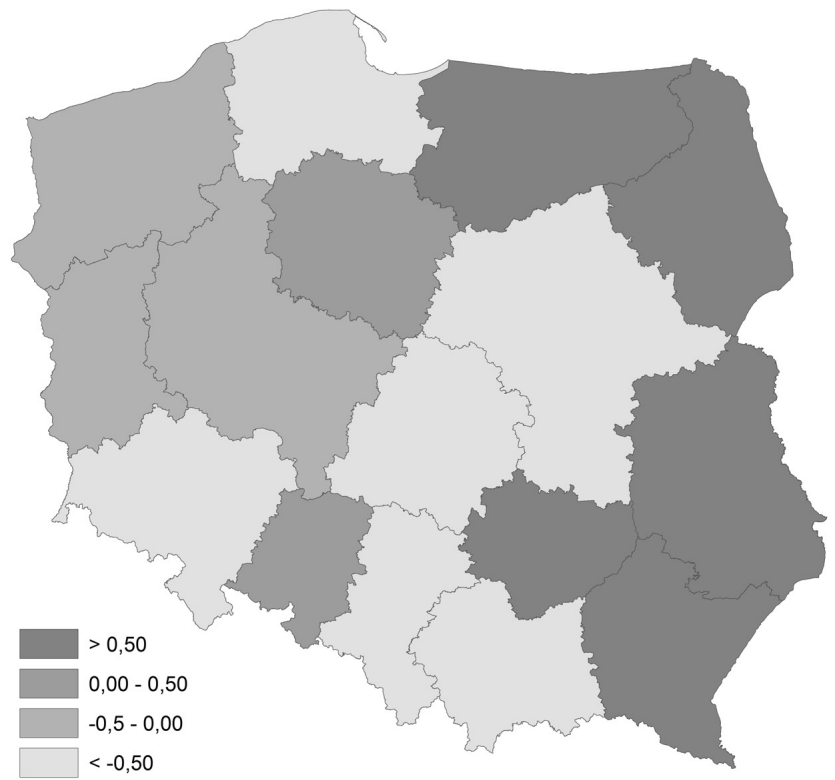

Ryc. 4. Syntetyczny wskaźnik poziomu absorpcji środków unijnych z RPO (wg odchylenia od średniej - $\sigma$ ) Synthetic indicator of EU funds absorption level derived from the ROP (by deviation from mean - $\sigma$ ) Źródło/Source: jak w tabeli 2.

\section{Wpływ środków unijnych na rozwój społeczno-gospodarczy - wybrane aspekty}

Rozwój społeczno-gospodarczy obszarów wiejskich jest kategorią szeroką, obejmującą nie tylko proces dywersyfikacji gospodarki (w kierunku dążenia do wielofunkcyjności), ale i aktywizację potencjału wewnętrznego regionu determinowanego przez posiadane zasoby (Romer 1990, 1994), nakłady inwestycyjne służące pokonywaniu barier wzrostu i wykorzystywanie mocnych stron regionu (Domański 2004) czy też przejawiającą się w pobudzaniu lokalnej przedsiębiorczości i zdolności do przyciągania inwestycji zewnętrznych (Heffner 2007). W podobnym tonie rzecz ujmuje K. Zawalińska (2008), która w swoich analizach podjęła próbę oceny skuteczności i efektywności funduszy unijnych we wspieraniu rozwoju obszarów wiejskich w ujęciu regionalnym. Na rolę efektywności procesu absorpcji funduszy strukturalnych, jako czynnika wpływającego na kształtowanie podstaw trwałego i zrównoważonego rozwoju lokalnego i regionalnego, uwagę zwraca wielu autorów m.in.: W. Ratajczak (2008), J. Duda (2006), M. Biczkowski (2009, 2010, 2013), P. Churski (2015), J. Rowiński (2007), R. Rudnicki (2010), a także autorzy licznych raportów ewaluacyjnych np. Ewaluacja ex-post... (2009), Ocena wpływu realizacji... (2011), Wpływ Wspólnej Polityki Rolnej... (2012).

Wyniki raportów oraz prowadzonych badań przedstawiających kwestię oddziaływania funduszy unijnych wieloaspektowo i przy zastosowaniu różnych metod wskazują wyraźnie, iż polskie regiony (ujmowane całościowo) cechują się znacznie wyższymi wskaźnikami ekonomicznymi aniżeli dekadę temu, u progu wejścia Polski do Unii Europejskiej. Znacznie zbliżyły się do średniego poziomu PKB per capita Unii Europejskiej. Wpływ na taki stan mają również środki unijne, aczkolwiek należy wyraźnie zastrzec, iż nie jest to jedyny 
czynnik rozwojowy, a raczej jeden z wielu. Dodatkowo na korzyść absorpcji funduszy UE, oprócz wymiaru stricte ekonomicznego, zaliczyć należy fakt, iż znacząco wpłynęły one na pobudzenie aktywności zarówno instytucji centralnych będących odpowiedzialnych za realizację konkretnych zadań (np. GDDKiA, PKP), jak i osób pracujących na rzecz rozwoju lokalnego i regionalnego, jak np. samorządy, przedsiębiorcy, przedstawiciele organizacji NGO, rolnicy, pracownicy instytucji kultury, sportu, sektora turystyki itd.

Różnice w efektywności oddziaływania środków na sytuację społeczno-gospodarczą wynikają z jednej strony ze struktury i wielkości transferów w obrębie poszczególnych RPO, z drugiej zaś z siły ekonomicznej każdego z regionów. Stąd jednym z ujęć, w oparciu o który dokonano oceny, jest wskaźnik obliczony jako stosunek udziału danego regionu w transferach środków z RPO do jego udziału w wielkości wytwarzanego PKB. Drugim punktem oceny była różnica zachodząca pomiędzy wskaźnikami syntetycznymi poziomu rozwoju społeczno-gospodarczego oraz poziomu absorpcji środków UE.

Analiza pierwszego z ujęć pozwala zaobserwować, iż największy udział (nominalnie) w pozyskiwaniu środków UE ma województwo mazowieckie (10,3\%), które jednocześnie w największym stopniu decyduje o PKB Polski (21,9\%; por. tab. 3, ryc. 6). Silna gospodarka regionu przekłada się zatem na wysokie możliwości absorpcyjne zewnętrznego kapitału. Kolejnym regionem z wysokim udziałem w wytwarzaniu krajowego PKB jest województwo śląskie $(12,7 \%)$, które jednak ma znacznie mniejszy udział w ogólnej absorpcji środków unijnych (5,5\%), co jest determinowane wysokim poziomem zurbanizowania i uprzemysłowienia tego regionu, a tym samym mniejszym wpływem obszarów wiejskich w alokacji środków unijnych rozdysponowanych poprzez regionalne programy operacyjne.

Do drugiej grupy można zaliczyć regiony, które cechuje odwrotna relacja. Ich udział w wytwarzaniu PKB jest niewielki, przy jednocześnie wysokim udziale w alokacji funduszy unijnych. Dotyczy to głównie województwa podkarpackiego, które wytwarza 3,9\% krajowego PKB, zaś do beneficjentów z tego regionu trafiło 9,5\% ogółu środków rozdysponowanych poprzez regionalne programy operacyjne. Do tej grupy zaliczają się także województwo warmińsko-mazurskie (analogicznie 2,7\% i 6,8\%) i świętokrzyskie (2,5\% i 6,4\%).

Kolejną grupę reprezentują województwa, których udział z wytwarzaniu PKB oraz w absorpcji środków unijnych jest zbliżony. Są to województwa: małopolskie (po 7,7\%), pomorskie $(5,8 \%$ i 5,6\%) czy wielkopolskie (9,5\% i 9,9\%). W tym przypadku ilość środków kierowanych do województw jest niejako adekwatna do ich wkładu w bilans PKB całego kraju.

Powyższe wyniki wskazują, że relatywnie największe znaczenie dla rozwoju obszarów wiejskich mają fundusze w województwach Polski wschodniej, o słabiej rozwiniętych lokalnych i regionalnych strukturach gospodarczych. Dla przykładu wskaźnik relacji udziału środków RPO do udziału w PKB w województwie świętokrzyskim wynosi 2,58, a w warmińsko-mazurskim 2,52 (por. tab. 3, ryc. 5). Rola funduszy UE w rozwoju gospodarek tychże regionów jest zatem istotna, zaś udział województw w podziale środków unijnych większy niż wynikałoby to z ich siły ekonomicznej. Do tej grupy zaliczają się także pozostałe województwa wschodniej części kraju (podkarpackie, lubelskie i podlaskie), jak i niektóre z części centralnej i zachodniej m.in.: kujawsko-pomorskie, lubuskie i opolskie.

Odmienną relację można zaobserwować w przypadku województw uznawanych za silne ekonomicznie, których udział w alokacji środków UE jest znacznie niższy, niż ich wkład w tworzenie PKB. Zalicza się tu głównie województwo śląskie (relacja 0,44) i mazowieckie $(0,47)$ a także dolnośląskie $(0,63)$ i łódzkie $(0,79)$. 
Tabela 3. Oddziaływanie funduszy UE na podstawowe wskaźniki społeczno-gospodarcze

\begin{tabular}{|c|c|c|c|c|c|c|}
\hline Jednostka terytorialna & 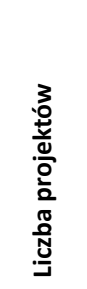 & 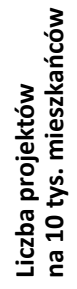 & 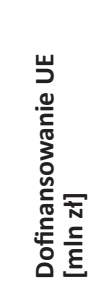 & 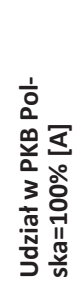 & 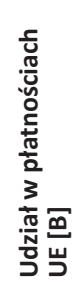 & $\begin{array}{l}\frac{1}{\infty} \\
\text { : } \\
\frac{0}{0} \\
\frac{0}{0} \\
\frac{0}{2}\end{array}$ \\
\hline Dolnośląskie & 887 & 3,0 & 1321,8 & 8,6 & 5,4 & 0,63 \\
\hline Kujawsko-pomorskie & 2062 & 9,8 & 1552,4 & 4,4 & 6,4 & 1,45 \\
\hline Lubelskie & 1577 & 7,3 & 1799,6 & 4,0 & 7,4 & 1,84 \\
\hline Lubuskie & 373 & 3,6 & 699,6 & 2,2 & 2,9 & 1,30 \\
\hline Łódzkie & 676 & 2,7 & 1181,4 & 6,1 & 4,8 & 0,79 \\
\hline Małopolskie & 1125 & 3,4 & 1875,5 & 7,7 & 7,7 & 1,00 \\
\hline Mazowieckie & 1038 & 2,0 & 2500,5 & 21,9 & 10,3 & 0,47 \\
\hline Opolskie & 521 & 5,1 & 735,6 & 2,1 & 3,0 & 1,44 \\
\hline Podkarpackie & 1435 & 6,7 & 2320,9 & 3,9 & 9,5 & 2,44 \\
\hline Podlaskie & 427 & 3,6 & 940,6 & 2,2 & 3,9 & 1,75 \\
\hline Pomorskie & 1038 & 4,5 & 1363,8 & 5,8 & 5,6 & 0,96 \\
\hline Śląskie & 1260 & 2,7 & 1348,8 & 12,7 & 5,5 & 0,44 \\
\hline Świętokrzyskie & 707 & 5,5 & 1570,8 & 2,5 & 6,4 & 2,58 \\
\hline Warmińsko-mazurskie & 994 & 6,8 & 1662,6 & 2,7 & 6,8 & 2,52 \\
\hline Wielkopolskie & 1382 & 4,0 & 2414,6 & 9,5 & 9,9 & 1,04 \\
\hline Zachodniopomorskie & 652 & 3,8 & 1098,5 & 3,8 & 4,5 & 1,19 \\
\hline Polska & 16154 & 4,7 & 24386,9 & 100,0 & 100,0 & 1,00 \\
\hline
\end{tabular}

Źródło/Source: obliczenia własne/own calculations.

W celu pogłębienia oceny warto porównać wartości wskaźników zastosowanych przy obliczaniu wskaźnika syntetycznego poziomu absorpcji środków z RPO (por. tab. 2). Jedną z przyjętych miar był udział funduszy pozyskanych przez beneficjentów z obszarów wiejskich w relacji do średniorocznego PKB regionów za lata 2007-2013. W województwach we wschodniej części kraju udział środków UE w PKB przekracza 4\% (świętokrzyskie, warmińsko-mazurskie, podkarpackie), podczas gdy w regionach gospodarczo silniejszych waha się w granicach 1-2\%, z wartościami skrajnymi w województwie śląskim $(0,7 \%)$ i mazowieckim (0,8\%). Również pozostałe z zastosowanych wskaźników potwierdzają obserwowane trendy. Taki rozkład wyników stanowi potwierdzenie relatywnie większego oddziaływania funduszy unijnych na rozwój obszarów wiejskich położonych w regionach o niższym poziomie rozwoju społeczno-gospodarczego.

Drugim z zastosowanych podejść jest analiza porównawcza syntetycznych wskaźników poziomu rozwoju społeczno-gospodarczego (por. tab. 1) i poziomu absorpcji środków UE (por. tab. 2). Różnica wartości obu wskaźników wskazuje na faktyczną różnicę między potencjałem wewnętrznym poszczególnych regionów, a ich aktywnością w pozyskiwaniu środków zewnętrznych, w tym przypadku ze źródeł UE. W takim ujęciu znaczące 


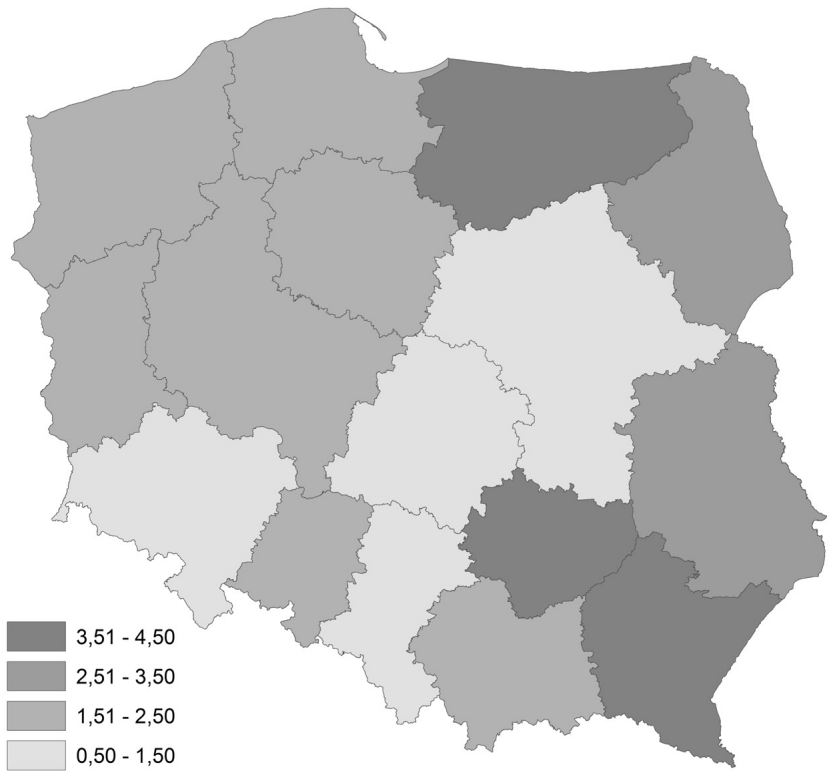

Ryc. 5. Relacja udziału w płatnościach z funduszy UE do udziału w PKB

Relation of share in payments from EU funds to the GDP share

Źródło/Source: opracowanie własne/own elaboration.

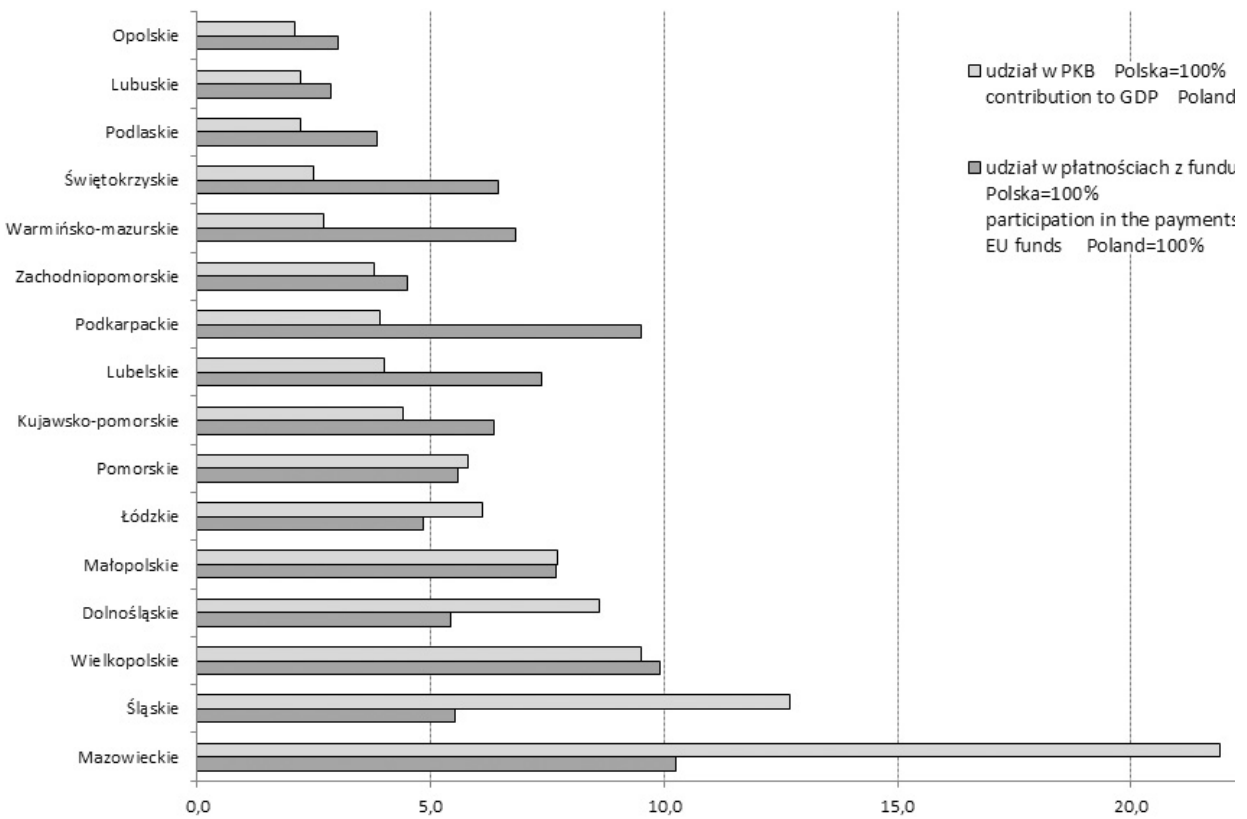

Ryc. 6. Udział województw w wytwarzanym PKB (Polska=100) oraz w ogólnej wielkości środków unijnych rozdysponowanych poprzez RPO

Share of voivodships in produced GDP (Poland $=100$ ) and in the total volume of EU funds allocated by the ROP Źródło/Source: opracowanie własne/own elaboration. 
oddziaływanie funduszy zauważalne jest w województwie świętokrzyskim, warmińsko-mazurskim i podkarpackim (różnica między wskaźnikami przekracza 2,00o), ponadto w lubelskim i podlaskim (różnica powyżej 1,00б) (por. ryc. 7). Z drugiej strony znajduje się województwo mazowieckie, które dysponując dużym potencjałem wewnętrznym,

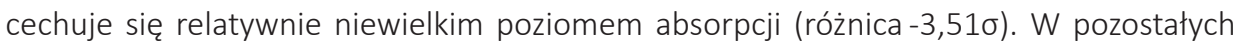
regionach dysproporcje nie są tak znaczące, tym niemniej w województwach o dużym potencjale gospodarczym absorpcja pozostaje na niższym względem średniej poziomie: śląskie $(-1,84 \sigma)$ dolnośląskie $(-1,43 \sigma)$ i wielkopolskie $(-1,27 \sigma)$. Wyniki te potwierdzają zależności obserwowane przy zastosowaniu pozostałych metod.

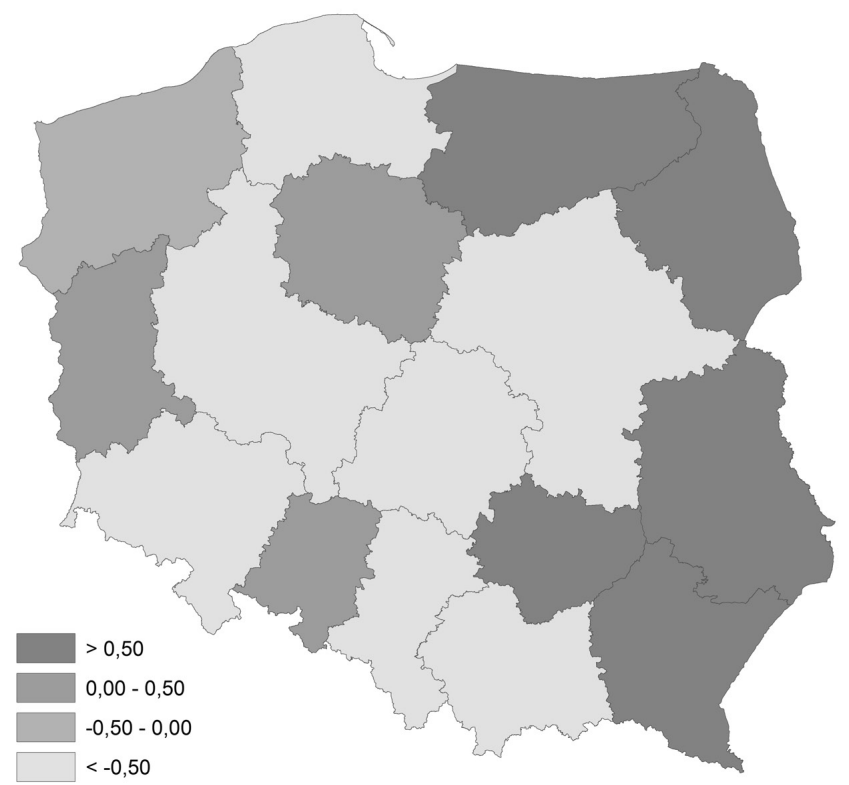

Ryc. 7. Wskaźnik oceny oddziaływania środków RPO w stosunku do poziomu rozwoju społeczno-gospodarczego - analiza porównawcza (wg różnicy wartości wskaźników syntetycznych $\sigma$ )

Assessment index for the impact of ROP funds compared to the level of socio-economic development-comparative analysis (by the difference in value of the synthetic indices $-\sigma$ )

Źródło/Source: opracowanie własne/own elaboration.

Oceniając oddziaływanie funduszy unijnych należy podkreślić, że o ile analizy prowadzone przy zastosowaniu wskaźników relacyjnych wskazują na większe oddziaływanie funduszy UE na lokalne procesy gospodarcze w jednostkach słabszych ekonomicznie, o tyle zastosowanie wartości nominalnych przynosi odmienne wnioski. Dodając do tego wyższy poziom rozwoju infrastrukturalnego oraz lepiej wykształcone struktury gospodarcze w regionach zamożniejszych, wpływa to na utrzymanie dysproporcji w rozwoju pomiędzy poszczególnymi regionami, w skrajnych przypadkach prowadząc do ich pogłębienia. Dostęp do funduszy UE wpłynął na zwiększenie gamy impulsów rozwojowych, które determinują rozwój obszarów wiejskich w poszczególnych regionach. Regiony słabsze ekonomicznie swój rozwój w większym stopniu opierają na możliwości pozyskiwania środków zewnętrznych oraz poprzez przyciąganie inwestorów, podczas gdy samorządy dysponujące znacznymi zasobami częściej szukają innych możliwości rozwojowych niż tylko poprzez absorpcję 
środków UE. Poprzez korzystniejsze uwarunkowania i posiadany potencjał wewnętrzny są mniej uzależnione od konieczności dofinansowywania przedsięwzięć ze środków UE i w większym stopniu są w stanie samodzielnie udźwignąć ciężar inwestycji.

Warto również podkreślić pośredni efekt oddziaływania funduszy UE, nieujmowany przez autorów w analizach i raportach ewaluacyjnych z racji trudności w ich obserwacji. Każde ze zrealizowanych przedsięwzięć dofinansowanych z RPO, pomimo różnej ich wartości czy zakresu wykonanych prac, ma istotne znaczenie w wymiarze lokalnym. Wszystkie inwestycje spełniają bowiem nie tylko podstawowe cele związane z zasadami wdrażania funduszy unijnych, jak np. wyrównywanie szans rozwojowych regionów słabiej rozwiniętych, w tym obszarów wiejskich czy aktywizacja i poprawa warunków życia mieszkańców wsi, ale generują popyt na materiały budowlane oraz usługi i urządzenia związane ze specyfiką danej inwestycji, które są wykonywane przez miejscowe firmy produkcyjno-usługowe. Przyczyniają się tym samym do tworzenia efektu synergicznego dającego większą korzyść niż tylko tą będącą sumą ogólnego bilansu absorpcji. Wpływa to na rozwój lokalnych przedsiębiorstw, poprawę sytuacji dochodowej mieszkańców wsi, poprawę poziomu i jakości życia, lepsze doposażenie w infrastrukturę techniczną i społeczną czy też na zmiany kształtujące wygląd przestrzeni wsi. Dzięki temu faktyczna rola funduszy unijnych w związku z rozwojem lokalnych gospodarek jest znacznie większa niż wskazuje na to jedynie analiza wskaźnikowa, a zarazem trudna do uchwycenia przy powszechnie stosowanych metodach i narzędziach. Dokładne rozpoznanie powyższego mechanizmu wymaga szczegółowych, pogłębionych analiz prowadzonych w mikroskali, w poszczególnych wsiach.

Ogólne wnioski, wynikające zarówno z niniejszego artykułu, jak i prowadzonych licznych badań ewaluacyjnych, wskazują, że realna konwergencja gospodarki polskiej jako całości może prowadzić do polaryzacji rozwoju, tj. sprzyjać dalszemu pogłębieniu różnic na poziomie regionalnym. O ile bowiem w ostatnim dwudziestoleciu polskie regiony zbliżyły się jako całość do średniego poziomu Unii Europejskiej ujmowanego per capita, to proces ten zachodzi nierównomiernie w wymiarze terytorialnym. Najbardziej dynamiczne są te województwa, w obrębie których znajdują się duże metropolie generujące i wzmacniające impulsy rozwojowe, podczas gdy regiony pozbawione silnie oddziaływującego ośrodka starają się raczej o to, by dystans rozwojowy nie ulegał powiększeniu (Biczkowski 2013).

\section{Podsumowanie}

Wyniki przeprowadzonej analizy roli i wpływu funduszy unijnych na rozwój poszczególnych jednostek terytorialnych, mierzone wartościami względnymi (relacyjnymi) w odniesieniu do posiadanego potencjału, wyraźnie wskazują, iż siła ich oddziaływania jest większa na obszarach o niższym poziomie rozwoju społeczno-gospodarczego. W tym przypadku środki UE stanowią istotny mechanizm wzmacniania tego rozwoju. Z drugiej strony konieczność współfinansowania inwestycji ze środków własnych, na które zostały przyznane fundusze UE, powoduje, iż większe możliwości absorpcyjne posiadają jednostki silniejsze ekonomicznie, stąd w ujęciu wartości bezwzględnych zarysowuje się ich przewaga.

W świetle przywołanej na wstępie koncepcji rozwoju neoendogennego, pozwala to na zaobserwowanie istotnych współzależności pomiędzy oddziaływaniem czynników endo i egzogenicznych. Koncepcja ta ma zastosowanie zarówno w przypadku indywidual- 
nych (punktowych) przedsięwzięć, służących rozwojowi jednostek oraz podmiotów z nią powiązanych, jak i w inwestycjach realizowanych najczęściej przez samorządy i służących ogółowi mieszkańców bądź większej grupie osób, instytucji i firm. W ten sposób wszyscy (pośrednio bądź bezpośrednio) odnoszą korzyść, co dodatkowo wpływa na podniesienie atrakcyjności i konkurencyjności gmin i przedsiębiorstw dla potencjalnych inwestorów, a także przyczynia się do wzrostu poziomu i jakości życia mieszkańców.

Koncepcja rozwoju neoendogenicznego zakłada poszukiwanie i wykorzystywanie wszystkich możliwych zasobów lokalnych w celu jak największej absorpcji potencjalnych czynników zewnętrznych, aby z kolei pomnażać zasoby własne (Biczkowski 2013). Jak zaznacza Gorlach (2005) rozwój egzogenny może prowadzić do marginalizacji zależnościowej, zaś rozwój endogenny może prowadzić do marginalizacji wykluczającej. Rozwój neoendogeniczny stanowi natomiast szansę uniknięcia powyższych zagrożeń, jako że próbuje wykorzystać obydwa typy czynników, dbając jednocześnie o dopływ zasobów zewnętrznych oraz waloryzację zasobów wewnętrznych. Koncepcja ta znajduje swoje potwierdzenie również w przypadku alokacji środków unijnych. Tym samym stanowi wiarygodne narzędzie ujmujące fundusze unijne jako element trwałego, stabilnego rozwoju, wpływającego na stymulowanie rozwoju społeczno-gospodarczego obszarów wiejskich przy wykorzystaniu ich wewnętrznego potencjału.

\section{$* * *$}

Artykuł przedstawia wyniki badań zrealizowanych w ramach projektu sfinansowanego ze środków Narodowego Centrum Nauki przyznanych na podstawie decyzji numer DEC-2012/07/B/HS4/00364

\section{Literatura}

Adamski T., Dzwonkowska K., Gorlach K., Pilachowski A., Starosta P., 2007, Wiedza w rozwoju zrównoważonym wsi, Uniwersytet Jagielloński, Kraków.

Biczkowski M., 2009, Wpływ środków unijnych na przeobrażenia i rozwój obszarów wiejskich, Roczniki Naukowe Stowarzyszenia Ekonomistów Rolnictwa i Agrobiznesu, 11, 4, Warszawa-Poznań-Olsztyn, s. 25-31.

Biczkowski M., 2010, Wybrane aspekty oceny wdrażania SPO „Restrukturyzacja i modernizacja sektora żywnościowego i rozwój obszarów wiejskich" w województwie kujawsko-pomorskim, [w:] R. Rudnicki (red.), Fundusze Unii Europejskiej jako czynnik modernizacji rolnictwa polskiego, Seria: Studia i Prace z Geografii i Geologii, 7, Bogucki Wydawnictwo Naukowe, Poznań, s. 113-125.

Biczkowski M., 2013, Przestrzenna alokacja wsparcia finansowego z instrumentów wspólnej polityki rolnej i ich wpływ na rozwój społeczno-gospodarczy obszarów wiejskich, [w:] M. Wójcik (red.), Koncepcje i problemy badawcze w geografii wsi, Acta Universitatis Lodziensis, Wyd. Uniwersytetu Łódzkiego, Łódź, s. 93-114.

Biczkowski M., 2013, Fundusze unijne jako czynnik rozwoju regionalnego w odniesieniu do koncepcji rozwoju neoendogenicznego, Studia Obszarów Wiejskich, 34, s. 71-85.

Churski P., Borowczak A., Perdał R., 2015, Czynniki rozwoju obszarów stagnacji w Polsce a ukierunkowanie interwencji środków unijnych, Studia Obszarów Wiejskich, 37, s. 115-130.

Domański R., 2004, Geografia ekonomiczna. Ujęcie dynamiczne, Wydawnictwo Naukowe PWN, Warszawa. 
Duda J., 2006, Regionalne Strategie Innowacji narzędziem zwiększania konkurencyjności polskich regionów, [w:] D. Kopycińska (red.), Kapitał ludzki jako czynnik rozwoju społeczno-gospodarczego, Microeconomics Department, Uniwersytet Szczeciński, Szczecin, s. 99-109.

Ewaluacja ex-post Planu Rozwoju Obszarów Wiejskich 2004-2006, 2009, IERiGŻ, IRWiR PAN, IUNiG, Warszawa.

Gorlach K., 2005, Przyszłość polskiej wsi a rola państwa polskiego, polityki rolnej UE oraz aktywności mieszkańców, Instytut Spraw Publicznych, Warszawa.

Heffner K., 2007, Rozwój społeczno-gospodarczy obszarów wiejskich, [w:] A. Rosner (red.), Zróżnicowanie poziomu rozwoju społeczno-gospodarczego obszarów wiejskich a zróżnicowanie dynamiki przemian, Instytut Rozwoju Wsi i Rolnictwa PAN, Warszawa, s. 11-26.

Klekotko M., 2005, Wiejskie społeczeństwo obywatelskie czy wiejskie społeczności obywatelskie? O problemach badania obywatelskości ludności wiejskiej, [w:] K. Gorlach, G. Foryś (red.), W obliczu zmiany: wybrane strategie działania mieszkańców polskiej wsi, Uniwersytet Jagielloński, Kraków, s. 107-117.

Koreleski K., 2007, Koncepcja rozwoju zrównoważonego w unijnej polityce kształtowania obszarów wiejskich, Infrastruktura i Ekologia Terenów Wiejskich PAN, 1, s. 19-26.

NSRO - Narodowe Strategiczne Ramy Odniesienia 2007-2013, 2006, Ministerstwo Rozwoju Regionalnego, Warszawa.

Racine J.B., Reymond H., 1977, Analiza ilościowa w geografii, PWN, Warszawa.

Ratajczak W., 2008, Innowacyjność a konkurencyjność polskich regionów, [W:] J.J. Parysek, T. Stryjakiewicz (red.), Region społeczno-ekonomiczny i rozwój regionalny, Bogucki Wydawnictwo Naukowe, Poznań, s. 299-313.

Ocena wpływu realizacji PROW 2007-2013 na gospodarkę Polski, 2011, Raport Instytutu Badań Strukturalnych, Warszawa.

Ray C., 1997, Towards a theory of the dialectic of rural development, Sociologia Ruralis, 27 (3), s. $345-362$.

Ray C., 2006, Neo-endogenous rural development in the EU, [w:] P. Cloke, T. Marsden, \& P. Mooney (red.), The handbook of rural studies, SAGE Publications Ltd., London, s. 278-292.

Romer P.M., 1990, Endogenous Technological Change, Quarterly Journal of Economics, 98, s. 71-102.

Romer P.M., 1994, The Origins of Endogenous Growth, Journal of Economic Perspectives, 8, s. 3-22.

Rowiński J., 2007, Wpływ funduszy UE na rozwój rolnictwa i obszarów wiejskich w pierwszych latach członkostwa, IERiGŻ, Warszawa.

Rudnicki R., 2010, Zróżnicowanie przestrzenne wykorzystania funduszy Unii Europejskiej przez gospodarstwa rolne w Polsce w latach 2004-2006, Seria: Studia i Prace z Geografii i Geologii, 17, Bogucki Wydawnictwo Naukowe, Poznań.

Wpływ funduszy europejskich na gospodarkę polskich regionów i konwergencję z krajami UE, średni wpływ w okresie 2004-2015, 2010, Raport, Ministerstwo Rozwoju Regionalnego, Instytu Badań nad Gospodarką Rynkową.

Wpływ Wspólnej Polityki Rolnej i Polityki Spójności na rozwój obszarów wiejskich, Raport końcowy, 2012, FundEko, Warszawa.

Wójcik M., 2010, Struktura i działanie - społeczno-geograficzna interpretacja oddziaływania funduszy Unii Europejskiej na przykładzie programu „Odnowa Wsi”, Studia Obszarów Wiejskich, 24, s. $186-201$.

Zawalińska K., 2008, Fundusze unijne: skuteczność i efektywność wspierania rozwoju obszarów wiejskich w Polsce, [w:] M. Drygas, A. Rosner (red.), Polska wieś i rolnictwo w Unii Europejskiej. Dylematy i kierunki przemian, Wyd. IRWiR PAN, Warszawa, s. 59-91. 


\section{Summary}

The article concerns the issue of the increasing development level of rural areas, which determines division into regions of dynamic growth and competing areas. Mitigating development might be achieved through adequate use of endogenous potential inherent in particular territorial units. This paper undertakes the issue of shaping sustainable socio-economic development of rural areas based on endogenous conditions as well as appropriate targeting of the EU funds to strengthen actions leading to the optimal use of resources. For a comprehensive assessment of funds impact for socio-economic development economic indicators and synthetic indexes were taken into consideration. These were calculated for the socio-economic (endogenous) development in rural areas (by region) and the level of absorption for the measures implemented by the 16 Regional Operational Programmes. Such procedure allowed to specify the relations and interdependencies that occur between these two levels. Results of the analysis were referred to the concept of neo-endogenous development. 
http://rcin.org.pl 